\title{
A Tutela Provisória do Processo Eleitoral no Novo Código de Processo Civil
}

\author{
The Interim Protection of the Electoral Process in the New \\ Civil Procedure Code
}

Oscar Valente Cardoso

Resumo: $\mathrm{O}$ artigo analisa a tutela provisória no novo Código de Processo Civil, subdividida em tutela de urgência (cautelar e antecipada) e da evidência, com as consequências que produzirá sobre a prática do processo eleitoral. Para esse fim, recorda as normas e as classificações doutrinárias das tutelas de urgência no CPC de 1973, com o fim de compará-las com o regramento do novo $\mathrm{CPC}$ e, consequentemente, as inovações deste e seus reflexos. Destaca a nova divisão da tutela provisória, a consolidação plena do sincretismo, com o fim do processo cautelar, além de analisar a concessão da tutela de urgência condicionada ao requerimento da parte, a estabilização da tutela antecipada, a responsabilidade civil objetiva da parte beneficiada pela tutela posteriormente revogada, as principais características e hipóteses de concessão da tutela da evidência, e normas de direito intertemporal.

Palavras-chave: Tutela Provisória. Código de Processo Civil. Processo Eleitoral.

\begin{abstract}
The article analyzes the interim protection in the new Civil Procedure Code, subdivided into injunctive relief (preventive and interlocutory) and evidence, with the consequences which will produce on the practice of the electoral process. For that purpose, it recalls the rules and doctrinal classifications of injunctive relief in CPC of 1973, in order to compare them with the rules of the new CPC and consequently, its innovations and consequences. It is remarkable the new division of interim protection, the full consolidation of syncretism, on termination of the injunction, in addition to analyzing the grant for injunctive relief dependent upon application of a party, the stabilization of anticipated judicial protection, the objective civil responsibility of the benefiting entity by the subsequent revocation of the judicial protection, the main characteristics and assumptions of granting the protection of evidence and rules of intertemporal law.
\end{abstract}

Keywords: Interim Protection. Civil Procedure Code. The Electoral Process. 


\section{Introdução}

O processo eleitoral no Brasil observa, tradicionalmente, um procedimento célere e com características jurisdicionais, administrativas e mistas, as quais demandam uma rápida solução. Pedidos de impugnação ao registro de candidatura, de inelegibilidade, representações por propaganda irregular ou para o exercício de direito de resposta, por exemplo, demandam a concessão de tutela provisória pelos juízes eleitorais para propiciar a utilidade do processo, a efetividade da prestação jurisdicional e a satisfação do direito material.

O novo Código de Processo Civil (Lei no 13.105/2015) modifica consideravelmente a regulamentação das tutelas cautelar e antecipada, inserindo-as como espécies do gênero tutela provisória, que, por sua vez, divide-se em tutela de urgência (acautelatória e antecipatória) e da evidência.

Este artigo examina as normas sobre tutela provisória no novo CPC (arts. 294 a 311, no Livro V, da Parte Geral), a partir de análise comparada com as normas do CPC de 1973, visando destacar as mudanças realizadas pelo novo Código e seus reflexos sobre o processo eleitoral.

\section{As Tutelas de Urgência no CPC de 1973}

As tutelas de urgência apoiam-se na existência de um risco iminente de dano ao direito material ou ao processo, sendo indispensáveis para a garantia de que o provimento jurisdicional final tenha eficácia e utilidade, ou seja, para que o bem da vida objeto do litígio seja atribuído a quem tiver direito sobre ele.

A necessidade de urgência justifica a existência de uma tutela anterior à sentença (ou ao seu cumprimento), motivo pelo qual são assim denominadas, a fim de evitar que o decurso do tempo prejudique a efetividade do processo ou do direito material. (BUENO, 2008, p. 288). ${ }^{1}$

A tutela de urgência subdivide-se em: (a) cautelar (ou acautelatória), de conteúdo preventivo, que busca garantir a efetividade da prestação jurisdicional; (b) e antecipada (ou antecipatória), de conteúdo satisfativo, a qual assegura o exercício do direito material controvertido

${ }^{1}$ BUENO, Cassio Scarpinella. Curso sistematizado de direito processual civil: teoria geral do direito processual civil. 3. ed. v. 1. São Paulo: Saraiva, 2008, p. 288. 
de forma provisória, no curso do processo, por aquele que demonstrar melhor a sua titularidade. (THEODORO JÚNIOR, 2004, p. 338-339). ${ }^{2}$

A classificação adotada não possui consenso doutrinário. Teori Zavascki (2009) divide a tutela jurisdicional em: (a) definitiva, apoiada no valor segurança, e que tem como principais atributos a cognição exauriente da lide e a imutabilidade da coisa julgada material; (b) e provisória, que privilegia o valor efetividade, e é caracterizada pela necessária relação com a tutela definitiva, a existência de uma situação de urgência, a cognição sumária, a limitação no tempo e a precariedade (sem formação de coisa julgada). ${ }^{3}$

Para Daniel Mitidiero (2013), a antecipação de tutela é uma técnica processual, enquanto a tutela cautelar é uma espécie de tutela jurisdicional do direito. ${ }^{4}$

É importante salientar, ainda, que nem toda tutela antecipatória (no sistema do $\mathrm{CPC} / 73$ ) é de urgência, pois, como será visto, além das situações prementes, também pode ser concedida como uma forma de sanção (para coibir o abuso do direito de defesa) ou até mesmo diante da inexistência de controvérsia sobre parte do pedido. (CÂMARA, 2008, p. 263 e 266). ${ }^{5}$ Por esta razão, como se verá adiante, o novo CPC utiliza a urgência como um dos critérios de diferenciação das tutelas de urgência.

\section{A Tutela Cautelar no CPC de 1973}

A tutela cautelar surgiu com a necessidade de assegurar que o processo tenha um resultado final útil, ou seja, que o bem jurídico pleiteado ainda exista, preferencialmente, na mesma situação em que se encontrava no início da demanda, para que a decisão judicial possa ter eficácia.

\footnotetext{
2 Nesse sentido, e utilizando a expressão "medidas provisórias": THEODORO JÚNIOR, Humberto. Curso de direito processual civil. v. I. 41. ed. Rio de Janeiro: Forense, 2004, p. 338-339.

3 ZAVASCKI, Teori Albino. Antecipação de tutela. 7. ed. São Paulo: Saraiva, 2009, pp. 18-40.

4 MITIDIERO, Daniel. Antecipação da tutela: da tutela cautelar à técnica antecipatória. São Paulo: RT, 2013, p. 17.

5 CÂMARA, Alexandre Freitas. Juizados especiais cíveis estaduais e federais: uma abordagem crítica. 4. ed. Rio de Janeiro: Lumen Juris, 2008, pp. 263 e 266.
}

Resenha Eleitoral (Florianópolis), v. 20, n. 1, p. 171-199, jul. 2016 
No entendimento de Humberto Theodoro Júnior ${ }^{6}$

é indispensável que a tutela jurisdicional dispensada pelo Estado a seus cidadãos seja idônea a realizar, em efetivo, o desígnio para o qual foi engendrada. Pois, de nada valeria, por exemplo, condenar o obrigado a entregar a coisa devida, se esta já inexistisse ao tempo da sentença. (THEODORO JÚNIOR, 2008, p. 540).

Teori Zavascki (2009) afirma que a tutela não definitiva pode propiciar: "[...] (a) providências antecipatórias do gozo do direito vindicado e (b) providências de garantia para a futura execução." ?

Em sentido amplo, a tutela cautelar abrange qualquer medida que objetive assegurar o resultado final de um processo, em andamento ou futuro, deferida incidentalmente no próprio processo ou em outro.

Regulamentado pelo Livro III do Código de Processo Civil de 1973, o processo cautelar é sempre dependente de outro processo, e pode ser instaurado anteriormente ou durante (medida preventiva ou incidental) o curso desse (art. 796, do CPC/73). ${ }^{8}$ Por isso, as medidas cautelares são classificadas como instrumentais, pois servem como um instrumento para outro processo, não tendo um fim em si mesmas. (THEODORO JÚNIOR, 2008, p. 543). ${ }^{9}$ Entre suas características destacam-se a preventividade (em relação ao dano, e não ao processo), a provisoriedade (é medida temporária, que pode ser transformada em definitiva no processo principal) e a acessoriedade (em relação ao processo principal). (MACHADO, 2004, p. 1193). ${ }^{10}$ Em consequência, o processo cautelar não tutela o direito, mas o processo principal, a fim de assegurar a eficácia e a utilidade do resultado desse.

Ressalta-se, assim, que, mesmo no CPC de 1973, a tutela cautelar não é prestada exclusivamente em processo autônomo. Os requisitos para a concessão da medida cautelar são mencionados nos arts. 798 e 801 do CPC/73, e consistem no fumus boni iuris e no periculum in mora.

\footnotetext{
6 THEODORO JÚNIOR, Humberto. Curso de direito processual civil. 42. ed. v. 2. Rio de Janeiro: Forense, 2008, p. 540.

7 ZAVASCKI, ob. cit., 2009, p. 27.

8 Art. 796. O procedimento cautelar pode ser instaurado antes ou no curso do processo principal e deste é sempre dependente.

9 THEODORO JÚNIOR, ob. cit., 2008, p. 543.

${ }^{10}$ MACHADO, Antônio Cláudio da Costa. Código de processo civil interpretado. 4. ed. Barueri: Manole, 2004, p. 1193.
} 
O fumus boni iuris é a plausibilidade do direito material, ou seja, a existência de indícios ou provas que demonstrem a existência do direito e a probabilidade de acolhimento, em tese, do pedido de sua efetivação no processo principal.

Já o periculum in mora é a possibilidade de que, com a demora na tramitação do processo principal, sua decisão final não tenha eficácia e utilidade, ou seja, o direito objeto da tutela não possa mais ser satisfeito. $\mathrm{O}$ art. 798 do $\mathrm{CPC} / 73$ exige que esse perigo seja derivado de um "fundado receio" (ou seja, uma situação objetiva o demonstre, e não somente haja uma intuição subjetiva do requerente), que o dano ocorra antes do julgamento do processo (e que a demora impeça ou dificulte a satisfação do direito), e que essa lesão seja grave e de difícil reparação (logo, caso não seja concedida a medida cautelar, dificilmente será possível o desfazimento do dano que for causado ao direito da parte). ${ }^{1 /}$

\section{A Tutela Antecipada no CPC de 1973}

A tutela antecipatória consiste em um provimento judicial que, liminarmente ou no curso do processo, concede provisoriamente à parte o objeto de seu alegado direito.

Daniel Mitidiero (2013) define-a como “[...] a técnica direcionada a antecipar de forma provisória mediante cognição sumária a tutela jurisdicional do direito à parte visando à distribuição isonômica do ônus do tempo no processo.”. ${ }^{12}$ Cássio Scarpinella Bueno (2009) conceitua-a como “[...] a possibilidade da precipitação da produção dos efeitos práticos da tutela jurisdicional, os quais, de outro modo, não seriam perceptíveis, isto é, não seriam sentidos no plano exterior ao processo [...] até um evento futuro [...].". ${ }^{13}$

Por ser provisória e de cognição sumária, não se pode esquecer que "antecipar efeitos da tutela continua significando prestar tutela juris-

11 Art. 798. Além dos procedimentos cautelares específicos, que este Código regula no Capítulo II deste Livro, poderá o juiz determinar as medidas provisórias que julgar adequadas, quando houver fundado receio de que uma parte, antes do julgamento da lide, cause ao direito da outra lesão grave e de difícil reparação.

12 MITIDIERO, ob. cit., 2013, p. 17.

13 BUENO, Cassio Scarpinella. Curso sistematizado de direito processual civil: tutela antecipada, tutela cautelar, procedimentos cautelares específicos. v. 4. São Paulo: Saraiva, 2009 , p. 9.

Resenha Eleitoral (Florianópolis), v. 20, n. 1, p. 171-199, jul. 2016 
dicional de natureza provisória, e, portanto, excepcional.” (ZAVASCKI, 2009, p. 75). ${ }^{14}$

E ainda: a antecipação dos efeitos da tutela é limitada pelo pedido, ou seja, não se pode requerer além do que poderá ser concedido no provimento jurisdicional final. (NERY JUNIOR et. al., 2014, p. 652). ${ }^{15}$

$\mathrm{O}$ art. 273 do $\mathrm{CPC} / 73$ trazia os principais fundamentos dessa espécie de tutela:

Art. 273. O juiz poderá, a requerimento da parte, antecipar, total ou parcialmente, os efeitos da tutela pretendida no pedido inicial, desde que, existindo prova inequívoca, se convença da verossimilhança da alegação e:

I - haja fundado receio de dano irreparável ou de difícil reparação; ou

II - fique caracterizado o abuso de direito de defesa ou o manifesto propósito protelatório do réu.

[...]

$\S 2^{\circ}$ Não se concederá a antecipação da tutela quando houver perigo de irreversibilidade do provimento antecipado.

Com base nesse dispositivo, exigiam-se os seguintes requisitos para o deferimento da tutela antecipatória: (a) requerimento da parte, em regra; (b) existência de prova inequívoca demonstrando as alegações da parte (fumus boni iuris); ${ }^{16}$ (c) receio fundado de dano irreparável ou de difícil reparação (periculum in mora), ou a demonstração do abuso de direito de defesa, ou do manifesto propósito protelatório do réu (um entre os três requisitos, ou seja, havia duas alternativas à prova do periculum in mora); (d) e a possibilidade de reversão da medida, na eventualidade do resultado final contrário à tutela antecipatória. (THEODORO JÚNIOR, 2004, p. 338-339). ${ }^{17}$

14 ZAVASCKI, ob. cit., p. 75

15 NERY JUNIOR, Nelson; NERY, Rosa Maria de Andrade. Código de processo civil comentado e legislação extravagante. 14. ed. São Paulo: RT, 2014, p. 652.

16 A expressão "prova inequívoca" gera críticas, pois pressupõe que existe prova que independa de valoração judicial para demonstrar os fatos narrados pela parte (MACHADO, Antônio Cláudio da Costa. Código de processo civil interpretado. 4. ed. Barueri: Manole, 2004, p. 352).

17 THEODORO JÚNIOR, Humberto. Curso de direito processual civil. v. I. 41. ed. Rio de Janeiro: Forense, 2004, p. 338-339. 
O $\S 6^{\circ}$ do art. 273 do CPC/73, incluído pela Lei nº 10.444/2002, trazia uma hipótese diferenciada de concessão da tutela antecipatória: "A tutela antecipada também poderá ser concedida quando um ou mais dos pedidos cumulados, ou parcela deles, mostrar-se incontroverso". Portanto, caso um dos fatos (e não dos pedidos, como equivocadamente mencionado no dispositivo) alegados no processo fosse incontroverso e, consequentemente, independesse de prova (art. 333, III, do CPC), poderia ser concedida a antecipação dos efeitos da tutela para o(s) pedido(s) relacionado(s) com esse fato, independentemente da existência dos requisitos acima listados. Isso ocorria quando o réu deixasse de contestar um dos pedidos, ou reconhecesse algum dos pedidos, ou confessasse parte dos fatos narrados na inicial, entre outras hipóteses. (MACHADO, 2004, p. 360-362). ${ }^{18}$

Diferentemente da tutela cautelar, que busca somente assegurar a utilidade e a eficácia da decisão final, a tutela antecipatória efetivamente concretiza o provável resultado do processo, mas de forma provisória, pois pode ser revogada ou alterada no curso do processo (art. 273, §4º, do $\mathrm{CPC} / 73$ ).

Sobre as semelhanças e distinções, Daniel Mitidiero (2013) afirma que

[...] não é possível confundir a técnica antecipatória com a tutela cautelar. A primeira consubstancia-se essencialmente em uma inversão procedimental e constitui uma técnica processual. É um meio para a realização de uma finalidade. A segunda é um dos fins possíveis resultantes do emprego do meio - é uma espécie de tutela jurisdicional do direito. (MITIDIERO, 2013, p.17). ${ }^{19}$

Para Humberto Theodoro Júnior,

tanto a medida cautelar $[\ldots]$ como a medida antecipatória $[\ldots]$ representam providências de natureza emergencial, executiva e sumária, adotadas em caráter provisório. O que, todavia, as distingue, em substância, é que a tutela cautelar apenas assegura uma pretensão, enquanto a tutela antecipatória realiza de imediato a pretensão. (THEODORO JÚNIOR, 2008, p. 549). ${ }^{20}$

18 MACHADO, Antônio Cláudio da Costa. Código de processo civil interpretado. 4. ed. Barueri: Manole, 2004, p. 360-362

19 MITIDIERO, Daniel. Ob. cit., 2013, p. 17.

20 THEODORO JÚNIOR, ob. cit., 2008, p. 549.

Resenha Eleitoral (Florianópolis), v. 20, n. 1, p. 171-199, jul. 2016 
Em síntese, a tutela cautelar tem uma função preventiva de garantir que o processo terá utilidade, e a decisão final poderá ser cumprida, e a tutela antecipatória tem função satisfativa, pois efetiva (ainda que temporariamente) o direito requerido pela parte.

As dificuldades surgidas na prática para diferenciar, em várias situações, as tutelas cautelar e antecipatória, levaram ao acréscimo do $\S 7^{\circ}$ ao art. 273 do CPC, pela Lei nำ10.444/2002, com a seguinte redação: "Se o autor, a título de antecipação de tutela, requerer providência de natureza cautelar, poderá o juiz, quando presentes os respectivos pressupostos, deferir a medida cautelar em caráter incidental do processo ajuizado.".

Trata-se da fungibilidade entre as medidas cautelar e antecipatória, que permite o deferimento da tutela correta mesmo que seja pleiteada a outra, inadequada para o caso concreto. Busca-se, com isso, evitar que a tutela de uma situação de risco (que pode fazer com que o processo perca sua utilidade e eficácia) seja denegada somente por aspectos formais do pedido.

Entretanto, essa fungibilidade não dispensa a parte interessada de demonstrar os requisitos da tutela correta. Assim, caso requeira, como medida cautelar, a antecipação dos efeitos da tutela, deverá comprovar a possibilidade de deferimento desta (cujos requisitos são, em regra, mais rigorosos), e não daquela. Neste sentido, conforme o entendimento do STJ: “[...] Esta Corte Superior já se manifestou no sentido da admissão da fungibilidade entre os institutos da medida cautelar e da tutela antecipada, desde que presentes os pressupostos da medida que vier a ser

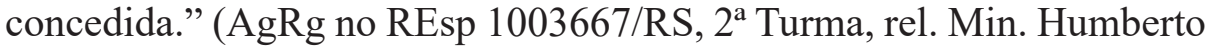
Martins, j. 19/05/2009, DJe 01/06/2009). ${ }^{21}$

\section{A Tutela Provisória no Novo CPC}

O novo CPC unificou as espécies de tutela liminar e provisória sob a denominação genérica de tutela provisória, regulamentada no Livro V da Parte Geral (arts. 294 a 311).

21 No mesmo sentido: REsp 889886/RJ, 2 ${ }^{\mathrm{a}}$ Turma, rel. Min. Humberto Martins, j. 07/08/2007, DJ 17/08/2007, p. 413; REsp 627759/MG, 3 ${ }^{\text {a }}$ Turma, rel. Min. Nancy Andrighi, j. 25/04/2006, DJ 08/05/2006, p. 198. 
A tutela provisória divide-se em: (a) tutela de urgência, com a mesma natureza daquela prevista no $\mathrm{CPC} / 73$, consistindo em proteção imediata a situações urgentes, sobre as quais há um risco (comprovado) de que não poderão ser prestadas no final do processo ${ }^{22}$; e (b) tutela da evidência, que se baseia exclusivamente na demonstração do direito, dispensada a prova do risco de dano (art. 294 do novo CPC).

O principal critério de distinção entre as duas espécies de tutela provisória é a urgência. Como a própria denominação indica, a tutela de urgência destina-se a situações inadiáveis, enquanto a tutela da evidência se destina a todas as outras formas de tutela provisória não urgentes, mas que são prestadas liminarmente em virtude da evidência do direito ${ }^{23}$.

Por outro lado, como ponto comum, ambas buscam assegurar o resultado útil do processo garantindo que a prestação jurisdicional possa ser efetiva, com a entrega do direito material a uma das partes ou assegurando a sua preservação, independentemente da medida (acautelatória ou antecipatória) adotada. Por essa razão, não se aplica a regra de incidência

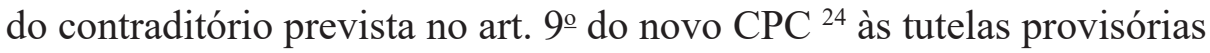
de urgência e da evidência, conforme dispõe o seu parágrafo único; isso

22 Sobre o conceito da tutela de urgência no novo CPC: “[...] a técnica processual empregada para impedir a consumação ou o agravamento do dano - o que pode consistir no agravamento do prejuízo ou no risco de que a decisão final seja ineficaz no plano dos fatos, que geram a necessidade de uma solução imediata - e que pode ser classificada coo a tutela de urgência. É, pois, a resposta do processo a uma situação de emergência, de perigo, de urgência." (WAMBIER, Teresa Arruda Alvim; CONCEIÇÃO, Maria Lúcia Lins; RIBEIRO, Leonardo Ferres da Silva; MELLO, Rogério Licastro Torres de. Primeiros comentários ao novo Código de Processo Civil artigo por artigo. São Paulo: RT, 2015, p. 498).

23 Na doutrina: "A tutela de urgência está precipuamente voltada a afastar o periculum in mora, sendo, portanto, para evitar m prejuízo grave ou irreparável enquanto dura o processo (agravamento do dano ou a frustração integral da provável decisão favorável), ao passo que a tutela de evidência baseia-se exclusivamente no alto grau de probabilidade do direito invocado, concedendo desde já aquilo que muito provavelmente virá ao final" (retirados os grifos em negrito do original) (WAMBIER, Teresa Arruda Alvim; CONCEIÇÃO, Maria Lúcia Lins; RIBEIRO, Leonardo Ferres da Silva; MELLO, Rogério Licastro Torres de. Primeiros comentários ao novo Código de Processo Civil artigo por artigo. São Paulo: RT, 2015, p. 487).

${ }^{24}$ Art. 9ํNão se proferirá decisão contra uma das partes sem que ela seja previamente ouvida. [...] Parágrafo único. O disposto no caput não se aplica: I - à tutela provisória de urgência; II - às hipóteses de tutela da evidência previstas no art. 311, incisos II e III; $[\ldots]$.

Resenha Eleitoral (Florianópolis), v. 20, n. 1, p. 171-199, jul. 2016 
significa que é possível conceder a tutela provisória em favor do autor sem a oitiva prévia do réu.

Em redação que pode induzir a interpretações equivocadas, o art. 295 do novo CPC prevê que "a tutela provisória requerida em caráter incidental independe do pagamento de custas". Entretanto, isso não significa que a tutela provisória antecedente pressupõe o pagamento de custas processuais (além daquelas que são devidas para o pedido de tutela definitiva), ou que exista um processo autônomo e próprio para as tutelas de urgência e da evidência. O novo CPC extinguiu o processo cautelar e não há nenhuma forma de tutela provisória que não seja dependente de um pedido de tutela definitiva, ou seja, será sempre acessória, independentemente de ser antecedente ou incidente. A única exceção, como se verá adiante, está na tutela antecipada estabilizada, que dispensa o pedido de tutela definitiva, mas, em razão disso, não tem seu mérito julgado.

Assim, o art. 295 busca apenas esclarecer que: (a) é devido o pagamento das custas processuais iniciais, no momento do protocolo da petição inicial, com os pedidos das tutelas provisória antecedente e definitiva; (b) e, se for requerida no curso do processo, não são devidas novas custas processuais para a tutela provisória incidental.

\section{As Tutelas de Urgência no Novo CPC}

A tutela de urgência observa a classificação do CPC/73 e é subdividida em (a) tutela antecipada; (b) e tutela cautelar.

Da mesma forma que no Código anterior, a tutela de urgência consiste na proteção de direito material (antecipada) ou processual (cautelar), por meio de cognição sumária e a adoção de providências práticas que buscam assegurar a efetividade do direito (material ou processual) no momento da entrega final da prestação jurisdicional.

Basicamente, enquanto a tutela cautelar assegura que o direito material seja conservado para ser passível de tutela no futuro, a tutela antecipada antecipa o próprio direito material ao autor. Em outras palavras, “[...] na cautelar protege-se para satisfazer, enquanto na tutela antecipada 
satisfaz-se para proteger." (WAMBIER, 2015, p. 488). ${ }^{25}$ De outro lado, como pontos comuns entre as duas espécies de tutela de urgência estão a cognição sumária, a precariedade (em regra) e a postergação do contraditório na concessão liminar (DINAMARCO, 2004, p. 55). ${ }^{26}$

Inovação importante está no fim do processo cautelar. Não há mais um Livro dedicado ao processo cautelar, tampouco o processo autônomo, em autos separados, com a finalidade exclusiva de prestar a tutela cautelar. O novo CPC concretiza de forma plena o sincretismo processual iniciado pela Lei $\mathrm{n}^{\mathrm{o}}$ 11.232/2005, que substituiu o processo de execução de sentença pelo cumprimento da sentença nos mesmos autos do processo de conhecimento. A partir da entrada em vigor do Código novo, as tutelas de cognição, cautelar e de execução serão prestadas em um só processo.

A precariedade também foi alterada quanto à tutela antecipada, a qual pode ser estabilizada, como se verá adiante.

Outro aspecto importante do novo CPC está na impossibilidade de concessão da tutela de urgência de ofício. Esse tema sempre foi polêmico no $\mathrm{CPC} / 73$, desde a alteração do art. 273 pela Lei no $8.952 / 94$.

Como visto, um dos requisitos para a concessão da tutela antecipada é o requerimento da parte, tendo em vista a previsão expressa de que "o juiz poderá, a requerimento da parte, [...]". Nesse sentido, parte da doutrina defende a impossibilidade da sua concessão de ofício, com base

25 WAMBIER, Teresa Arruda Alvim; CONCEIÇÃO, Maria Lúcia Lins; RIBEIRO, Leonardo Ferres da Silva; MELLO, Rogério Licastro Torres de. Primeiros comentários ao novo Código de Processo Civil artigo por artigo. São Paulo: RT, 2015, p. 488.

${ }^{26}$ Sobre o assunto: DINAMARCO, Cândido Rangel. Nova era no processo civil. São Paulo: Malheiros, 2004, p. 55. 
na redação do art. 273 e no princípio da inércia da jurisdição previsto no art. $2^{\circ}$ do $\mathrm{CPC} / 73^{27}$ (e reiterado no art. $2^{2}$ do novo CPC). ${ }^{28}$

De outro lado, alguns autores defendiam a sua possibilidade com fundamento no $\$ 3^{\circ}$ - do art. 273 do CPC/73, segundo o qual "a efetivação da tutela antecipada observará, no que couber e conforme sua natureza, as normas previstas nos arts. 588, 461, $\S 4^{\circ}$ e $5^{\circ}$, e 461-A”. Por sua vez, o art. 461, §5, do CPC/73, permitia ao juiz, de ofício, determinar as medidas necessárias para a efetivação da tutela específica por ele prestada. Entretanto, o dispositivo não trata de concessão de ofício da medida, mas apenas da adoção, de ofício, de medidas que permitam ou facilitem o cumprimento da decisão judicial ${ }^{29}$.

No Superior Tribunal de Justiça a questão também gera controvérsia. Há acórdãos admitindo a concessão de ofício da tutela antecipada, com base no poder geral de cautela do juiz (art. 798 do CPC/73) e na fungibilidade das tutelas de urgência (art. 273, §7으, do CPC/73), no dever do juiz em assegurar a efetividade do processo, e na autorização

27 "Não há antecipação dos efeitos da sentença sem provocação da parte." (WAMBIER, Luiz Rodrigues; TALAMINI, Eduardo Talamini. Curso avançado de processo civil. v. 1. 13. ed. São Paulo: RT, 2013, p. 407). Ainda: "Tendo em vista que ne procedat iudex ex officio, conforme dispõe o art. $2^{\circ}$ do CPC, estando o juiz adstrito aos limites do pedido formulado, temos também que a antecipação de tutela só deve ser concedida se houver requerimento nesse sentido, norma expressa, aliás, no caput do art. 273" (ALVIM, Arruda; ASSIS, Araken de; ALVIM, Eduardo Arruda. Comentários ao Código de Processo Civil. 2. ed. São Paulo: RT, 2012, p. 604). Com o mesmo entendimento: "O primeiro requisito para a concessão da antecipação da tutela é o requerimento da parte. Isto porque, ex legis, não poderá o juiz antecipar a tutela de ofício." (VAZ, Paulo Afonso Brum. Manual da tutela antecipada: doutrina e jurisprudência. Porto Alegre: Livraria do Advogado, 2002, p. 130). Nelson Nery Jr. e Rosa Maria de Andrade Nery defendem, em princípio, a inviabilidade da concessão de ofício, mas a admitem em determinadas situações excepcionais, como na situação de ação trabalhista proposta pelo empregado sem a assistência de advogado (NERY JUNIOR, Nelson; NERY, Rosa Maria de Andrade. Código de processo civil comentado e legislação extravagante. 14. ed. São Paulo: RT, 2014, pp. 653-654).

28 Art. $2^{\mathrm{o}} \mathrm{O}$ processo começa por iniciativa da parte e se desenvolve por impulso oficial, salvo as exceções previstas em lei.

$29 \S 5^{\circ}$ Para a efetivação da tutela específica ou a obtenção do resultado prático equivalente, poderá o juiz, de ofício ou a requerimento, determinar as medidas necessárias, tais como a imposição de multa por tempo de atraso, busca e apreensão, remoção de pessoas e coisas, desfazimento de obras e impedimento de atividade nociva, se necessário com requisição de força policial. 
legal para a concessão de ofício de medidas antecipatórias de caráter mandamental (art. 461, §5을 do CPC/73). ${ }^{30}$

O novo CPC deixa bastante claro que a tutela provisória (gênero) depende do requerimento da parte, em seus arts. 295 ("a tutela provisória requerida") e 299 ("a tutela provisória será requerida ao juízo da causa"). Previsões similares são encontradas na tutela antecipada antecedente - art. 303 ("a petição inicial pode limitar-se ao requerimento da tutela antecipada [...]"), e na tutela cautelar antecedente - art. 305 ("A petição inicial da ação que visa à prestação de tutela cautelar [...]"). Portanto, todas as hipóteses de tutela de urgência no novo CPC dependem de requerimento da parte.

Contudo, da mesma forma que no $\mathrm{CPC} / 73$ (art. 273, $\S^{\circ}{ }^{\circ}{ }^{31}$, o novo CPC permite a modificação e a revogação de ofício da tutela de urgência, em seu art. 296: "A tutela provisória conserva sua eficácia na pendência do processo, mas pode, a qualquer tempo, ser revogada ou modificada.".

${ }^{30}$ PROCESSUAL CIVIL. PREVIDENCIÁRIO. SALÁRIO-MATERNIDADE. TUTELA ANTECIPADA DE OFÍCIO CONCEDIDA NO ACÓRDÃO. ADMISSIBILIDADE EM HIPÓTESES EXCEPCIONAIS. [...] 2. As tutelas de urgência são identificadas como reação ao sistema clássico pelo qual primeiro se julga e depois se implementa o comando, diante da demora do processo e da implementação de todos os atos processuais inerentes ao cumprimento da garantia do devido processo legal. Elas regulam situação que demanda exegese que estabeleça um equilíbrio de garantias e princípios (v.g., contraditório, devido processo legal, duplo grau de jurisdição, direito à vida, resolução do processo em prazo razoável). [...] 5. A doutrina admite, em hipóteses extremas, a concessão da tutela antecipada de ofício, nas 'situações excepcionais em que o juiz verifique a necessidade de antecipação, diante do risco iminente de perecimento do direito cuja tutela é pleiteada e do qual existam provas suficientes de verossimilhança' (José Roberto dos Santos Bedaque, Tutela cautelar e tutela antecipada: tutelas sumárias e de urgência, $4^{a}$ ed., São Paulo, Malheiros, 2006, pp. 384-385). 6. A jurisprudência do STJ não destoa em situações semelhantes, ao reconhecer que a determinação de implementação imediata do benefício previdenciário tem caráter mandamental, e não de execução provisória, e independe, assim, de requerimento expresso da parte. (v. AgRg no REsp 1.056.742/RS, Rel. Min. Napoleão Nunes Maia Filho, DJe de 11.10.2010 e REsp 1.063.296/RS, Rel. Min. Og Fernandes, Dje de 19.12.2008). 7. Recurso Especial não provido" (REsp 1309137/MG, 2 ${ }^{\text {a }}$ Turma, rel. Min. Herman Benjamin, j. 08/05/2012, DJe 22/05/2012).

$31 \S 4^{\mathrm{o}}$ A tutela antecipada poderá ser revogada ou modificada a qualquer tempo, em decisão fundamentada".

Resenha Eleitoral (Florianópolis), v. 20, n. 1, p. 171-199, jul. 2016 
A tutela de urgência (antecipada e cautelar) possui dois requisitos genéricos, previstos no art. 300 do novo CPC ${ }^{32}$ : (a) a probabilidade do direito; (b) e o perigo de dano (na tutela antecipada) ou o risco ao resultado útil do processo (na tutela cautelar).

Portanto, não se exige mais a "prova inequívoca" prevista no $\mathrm{CPC} / 73$, mas a probabilidade do direito, consistente na cognição sumária sobre quem é o provável titular do direito (autor ou réu), para deferir - ou não - a tutela de urgência. (AMARAL, 2015). ${ }^{33}$

O juiz pode acrescentar uma condição para a concessão da tutela de urgência, consistente na caução real ou fidejussória, com o objetivo de ressarcir os danos que a outra parte possa vir a sofrer com a medida ( $1^{\circ}$ do art. 300 do novo CPC), ${ }^{34}$ ressalvando-se, contudo, a dispensa dessa exigência quando a parte beneficiada pela tutela de urgência for economicamente hipossuficiente e não puder prestá-la.

Portanto, em resumo: (a) em regra, a parte não tem a obrigação de prestar caução para a obtenção da tutela de urgência; (b) excepcionalmente, e com fundamento nas peculiaridades do caso e na necessidade de garantir o ressarcimento de danos eventualmente causados à parte contrária com a concessão da tutela de urgência, o juiz pode determinar que a parte beneficiada preste caução, real ou fidejussória; e, (c) nessa situação excepcional, o juiz pode dispensar a caução quando a parte beneficiada com a tutela de urgência comprovar sua hipossuficiência econômica.

Ainda, na ausência de prova documental suficiente, o juiz pode determinar a realização de audiência de justificação prévia para a concessão liminar da tutela de urgência ( $\$ 2^{\circ}$ do art. 300 do novo CPC). ${ }^{35}$

32 Art. 300. A tutela de urgência será concedida quando houver elementos que evidenciem a probabilidade do direito e o perigo de dano ou o risco ao resultado útil do processo.

33 AMARAL, Guilherme Rizzo. Comentários às alterações do novo CPC. São Paulo: RT, 2015.

34 §1 Para a concessão da tutela de urgência, o juiz pode, conforme o caso, exigir caução real ou fidejussória idônea para ressarcir os danos que a outra parte possa vir a sofrer, podendo a caução ser dispensada se a parte economicamente hipossuficiente não puder oferecê-la.

$35 \S 2^{\circ}$ A tutela de urgência pode ser concedida liminarmente ou após justificação prévia. 
Há, por outro lado, um requisito contrário à concessão da tutela de urgência, consistente no perigo de irreversibilidade dos efeitos da decisão ( $\$ 3$ o do art. 300 do novo CPC). ${ }^{36}$ Isto significa que, caso a tutela de urgência pretendida possa se tornar definitiva (na prática) antes do trânsito em julgado da decisão de mérito, ou seja, de forma que impossibilite o retorno ao status quo ante na hipótese de o julgamento ser contrário ao beneficiado por aquela, sua concessão é vedada, ainda que estejam presentes todos os requisitos para a sua concessão.

Na prática, entretanto, essa proibição não é absoluta e, com base em outras normas, a tutela de urgência pode ser concedida ainda que haja perigo de irreversibilidade. Neste sentido é o que prevê o Enunciado no 25 da ENFAM: "A vedação da concessão de tutela de urgência cujos efeitos possam ser irreversíveis (art. 300, §3ำ do CPC/2015) pode ser afastada no caso concreto com base na garantia do acesso à Justiça (art. 5o, XXXV, da CRFB).”.

A tutela de urgência cautelar pode ser: (a) nominada (típica), com previsão expressa no $\mathrm{CPC}$, que compreende apenas o arresto, o sequestro, o arrolamento de bens e o registro de protesto contra alienação de bem; e (b) inominada (atípica), que, apesar de não especificamente prevista no Código, é concedida com base no poder geral de cautela (art. 301 do novo $\mathrm{CPC}$ ). ${ }^{37}$ Contudo, ao contrário do $\mathrm{CPC} / 73$, o qual estabelece procedimento próprio para cada tutela cautelar típica, o novo CPC não estabelece procedimentos diferenciados para as tutelas de urgência cautelares, típicas ou atípicas.

Essa denominação será utilizada para designar apenas a medida cautelar, diante da inexistência de processo cautelar no novo Código.

Recorda-se que, no novo CPC, as duas espécies de tutela de urgência (cautelar e antecipada) podem ser prestadas de forma: (a) antecedente, quando a urgência for demonstrada antes da propositura do pedido principal, e é analisada em medida liminar, com a apresentação posterior

36 §3ำ A tutela de urgência de natureza antecipada não será concedida quando houver perigo de irreversibilidade dos efeitos da decisão.

37 Art. 301. A tutela de urgência de natureza cautelar pode ser efetivada mediante arresto, sequestro, arrolamento de bens, registro de protesto contra alienação de bem e qualquer outra medida idônea para asseguração do direito.

Acerca da manutenção do poder geral de cautela pelo novo Código, dispõe o Enunciado no 31 do FPPC: “(art. 301) O poder geral de cautela está mantido no CPC.”.

Resenha Eleitoral (Florianópolis), v. 20, n. 1, p. 171-199, jul. 2016 
do pedido de tutela definitiva; ou (b) incidental, quando a urgência ocorrer no curso do processo, a partir da apresentação do pedido inicial. Por exemplo: se na petição inicial o autor apresentar os pedidos da tutela provisória de urgência cautelar e da tutela definitiva, aquela será incidental.

A tutela provisória é antecedente quando apresentada antes da definitiva. Trata-se de outra inovação, considerando que no CPC de 1973 apenas a tutela cautelar podia ser prestada em caráter antecedente ou incidental (art. 796) ${ }^{38}$, enquanto a tutela antecipada era apenas incidental, ou seja, não podia ser apresentada antes do pedido principal.

O novo CPC regulamenta em dispositivos em separado ao procedimento das tutelas antecipada (arts. 303 e 304) e cautelar (arts. 305 a 310), quando requeridas em caráter antecedente.

Ainda assim, não há um processo autônomo, tendo em vista que a tutela antecipada é requerida na petição inicial, juntamente com o pedido de tutela definitiva. $\mathrm{O}$ art. 303 ressalva que a tutela antecipada antecedente pode esgotar o objeto do pedido:

“[...] a petição inicial pode limitar-se ao requerimento da tutela antecipada e à indicação do pedido de tutela final, com a exposição da lide, do direito que se busca realizar e do perigo de dano ou do risco ao resultado útil do processo.”.

Recorda-se que a tutela provisória de urgência é uma das exceções ao contraditório prévio e da necessidade de se ouvir a parte contrária antes de proferir decisão contra ela (art. 9o, parágrafo único, I, novo CPC). ${ }^{39}$ Logo, o juiz pode deferir a tutela de urgência cautelar ou antecipada antecedente sem que isso descumpra o direito da parte contrária ao contraditório, mas, se essa decisão puder causar tal violação, deve postergá-la para momento posterior à manifestação do réu. ${ }^{40}$

\footnotetext{
38 Art. 796. O procedimento cautelar pode ser instaurado antes ou no curso do processo principal e deste é sempre dependente.

39 Art. 9o Não se proferirá decisão contra uma das partes sem que ela seja previamente ouvida. Parágrafo único. O disposto no caput não se aplica: I - à tutela provisória de urgência $[\ldots]^{\prime}$.'

40 Nesse sentido é o teor do Enunciado no 30 do FPPC: “(art. 298) O juiz deve justificar a postergação da análise liminar da tutela provisória sempre que estabelecer a necessidade de contraditório prévio".
} 
A regulamentação da tutela de urgência antecedente é diferenciada porque o novo CPC admite a estabilização da tutela antecipada em seu art. 304: "A tutela antecipada, concedida nos termos do art. 303, torna-se estável se da decisão que a conceder não for interposto o respectivo recurso." ${ }^{41}$.

Essa estabilização consiste na manutenção da eficácia da decisão que deferir a antecipação dos efeitos da tutela, independentemente de instrução posterior ou de sentença de mérito. Não havendo recurso, a decisão em cognição sumária se torna estável e o processo não segue até o julgamento final, devendo o juiz proferir sentença de extinção do processo sem resolução do mérito. ${ }^{42} \mathrm{E}$ ainda, como estímulo ao comportamento cooperativo e não litigioso, o réu fica isento do pagamento de custas processuais finais, e o juiz deve fixar os honorários de sucumbência em percentual reduzido ( $5 \%$ sobre o valor da causa). ${ }^{43}$

No entanto, essa estabilização não tem força de coisa julgada (art. 304, § 6o $),{ }^{44}$ considerando que são apenas os efeitos da tutela antecipada que se prolongam no tempo, e não o conteúdo da decisão. Por essa razão, a tutela antecipada estável só pode ser revista, reformada ou invalidada por ação própria (ação de revisão, reforma ou invalidação), a qual possui requisitos próprios e não se confunde com a ação rescisória.

41 Ainda, há quem defenda a possibilidade de estabilização da tutela antecipada em outras hipóteses, desde que expressamente admitidas pelas partes em negócio jurídico processual, nos termos do art. 190 do novo CPC. Nesse sentido é o Enunciado no 32 do FPPC “(art. 304) Além da hipótese prevista no art. 304, é possível a estabilização expressamente negociada da tutela antecipada de urgência antecedente".

$42 \mathrm{O} \S 1^{\circ}$ do art. 304 não esclarece a natureza dessa sentença, por referir laconicamente que "No caso previsto no caput, o processo será extinto". Contudo, tendo em vista que a decisão não faz coisa julgada material (art. 304, § 6oo ), é evidente que a sentença extingue o processo sem resolução de mérito, permanecendo estáveis apenas os efeitos da decisão que concedeu a tutela de urgência antecipada.

43 Conforme prevê o Enunciado no 18 da ENFAM: "Na estabilização da tutela antecipada, o réu ficará isento do pagamento das custas e os honorários deverão ser fixados no percentual de 5\% sobre o valor da causa (art. 304, caput, c/c o art. 701, caput, do CPC/2015).”.

44 Art. 304. [...] §6o A decisão que concede a tutela não fará coisa julgada, mas a estabilidade dos respectivos efeitos só será afastada por decisão que a revir, reformar ou invalidar, proferida em ação ajuizada por uma das partes, nos termos do §2o deste artigo.”. Ainda, nos termos do Enunciado no 27 da ENFAM: "Não é cabível ação rescisória contra decisão estabilizada na forma do art. 304 do CPC/2015.”. 
${ }^{45}$ Essa ação deve ser proposta pelo réu no prazo decadencial de 2 anos, de acordo com o procedimento previsto nos $\S \S 2^{\circ}$ a $6^{\circ}$ do art. 304. (WAMBIER et. al., 2015, p. 510). ${ }^{46}$ A referida ação de revisão, reforma ou invalidação, também pode conter uma decisão de antecipação de tutela, ou seja, o juiz pode deferir tutela de urgência para suspender os efeitos da tutela antecipada estável do processo anterior. ${ }^{47}$

Já a tutela cautelar antecedente, apesar de inicialmente ter aparência de processo cautelar por iniciar apenas com o seu requerimento (art. 305) ${ }^{48}$, passa a ter o pedido principal nos mesmos autos, a ser apresentado pelo autor no prazo de 30 dias, contados a partir da efetivação da tutela (art. 308) ${ }^{49}$. Além disso, o $§ 1^{\circ}$ do art. 308 do novo CPC prevê que "o pedido principal pode ser formulado conjuntamente com o pedido de tutela cautelar.".

No mais, o procedimento da tutela de urgência incidental é similar nas espécies antecipada e cautelar.

$\mathrm{O}$ art. 302 do CPC/2015 traz uma inovação sobre as consequências prejudiciais causadas à outra parte pela concessão da tutela de ur-

45 Sobre o tema, dispõe o Enunciado n 33 do FPPC “(art. 304, §§) Não cabe ação rescisória nos casos estabilização da tutela antecipada de urgência.”.

46 "O que se pretende é que a decisão proferida em sede de antecipação de tutela, no âmbito do procedimento antecedente produza e mantenha seus efeitos, independentemente da continuidade do processo de cognição plena, quando as partes conformam-se com tal decisão. Se as partes ficam satisfeitas com a decisão que concedeu a tutela antecipada, baseada em cognição sumária e sem força de coisa julgada, o NCPC não as obriga a prosseguir no processo, para obter uma decisão de cognição plena, com força de cosa julgada material" (WAMBIER, Ob. cit., 2015, p. 510).

47 De acordo com o Enunciado no 26 da ENFAM: "Caso a demanda destinada a rever, reformar ou invalidar a tutela antecipada estabilizada seja ajuizada tempestivamente, poderá ser deferida em caráter liminar a antecipação dos efeitos da revisão, reforma ou invalidação pretendida, na forma do art. 296, parágrafo único, do CPC/2015, desde que demonstrada a existência de outros elementos que ilidam os fundamentos da decisão anterior".

48 Art. 305. A petição inicial da ação que visa à prestação de tutela cautelar em caráter antecedente indicará a lide e seu fundamento, a exposição sumária do direito que se objetiva assegurar e o perigo de dano ou o risco ao resultado útil do processo.

49 Art. 308. Efetivada a tutela cautelar, o pedido principal terá de ser formulado pelo autor no prazo de 30 (trinta) dias, caso em que será apresentado nos mesmos autos em que deduzido o pedido de tutela cautelar, não dependendo do adiantamento de novas custas processuais. 
gência: a responsabilidade civil objetiva da parte beneficiada pela tutela posteriormente revogada, nas seguintes hipóteses:

Art. 302. Independentemente da reparação por dano processual, a parte responde pelo prejuízo que a efetivação da tutela de urgência causar à parte adversa, se:

I - a sentença lhe for desfavorável;

II - obtida liminarmente a tutela em caráter antecedente, não fornecer os meios necessários para a citação do requerido no prazo de 5 (cinco) dias;

III - ocorrer a cessação da eficácia da medida em qualquer hipótese legal;

IV - o juiz acolher a alegação de decadência ou prescrição da pretensão do autor.

Parágrafo único. A indenização será liquidada nos autos em que a medida tiver sido concedida, sempre que possível.

Portanto, independentemente da existência de culpa e dolo da parte beneficiada pela tutela, caso ocorra alguma das citadas situações, e existindo nexo de causalidade entre o fato (tutela de urgência) e o dano causado à parte contrária, surge o dever de indenizar, a ser cumprido, preferencialmente, nos mesmos autos.

\section{A Tutela da Evidência no Novo CPC}

A tutela provisória da evidência, como visto, consiste em espécie de tutela provisória baseada na demonstração do direito da parte, ainda que não haja nenhum risco à efetividade do direito material ${ }^{50}$ - é tutela provisória sem urgência. O requisito principal da tutela da evidên-

50 Sobre a tutela de evidência, na doutrina: "Há situações em que o direito invocado pela parte se mostra com u grau de probabilidade tão elevado, que se torna evidente. Nessas hipóteses, não se conceber um tratamento diferenciado, pode ser considerado com uma espécie de denegação de justiça, pois, certamente, haverá o sacrifício do autor diante do tempo do processo" (WAMBIER, Ob. cit., 2015, p. 523). Ainda: "A concessão da 'tutela de evidência' independe da demonstração de perigo de dano ou de risco ao resultado útil do processo, isto é, para empregar a expressão geralmente usada para descrever uma e outra situação do periculum in mora" (BUENO, Cassio Scarpinella. Novo Código de Processo Civil anotado. São Paulo: Saraiva, 2015, p. 231).

Resenha Eleitoral (Florianópolis), v. 20, n. 1, p. 171-199, jul. 2016 
cia é, portanto, a comprovação de evidência do direito material da parte autora, independentemente de prova de dano ou risco de dano. ${ }^{51}$

A principal distinção entre as tutelas da evidência e de urgência está na urgência, exigida na segunda e dispensada na primeira. Essa divisão da tutela provisória em duas espécies busca diferenciar a natureza da proteção e os requisitos necessários para a concessão de cada uma delas.

Também se distingue a tutela da evidência do julgamento antecipado do mérito, total ou parcial (arts. 355 e 356 do novo CPC) - a primeira é decisão em cognição sumária e provisória, enquanto o segundo decorre de cognição exauriente e definitiva da lide.

Enquanto a tutela de urgência é mais abrangente e confere discricionariedade ao juiz, que constrói em cada decisão o conceito de urgência, a tutela da evidência é restrita, considerando que é evidente $o$ direito que o legislador assim considerar.

$\mathrm{O}$ art. 311 do CPC/2015 regulamenta a tutela da evidência, permitida em quatro situações:

Art. 311. A tutela da evidência será concedida, independentemente da demonstração de perigo de dano ou de risco ao resultado útil do processo, quando:

I - ficar caracterizado o abuso do direito de defesa ou o manifesto propósito protelatório da parte;

II - as alegações de fato puderem ser comprovadas apenas documentalmente e houver tese firmada em julgamento de casos repetitivos ou em súmula vinculante;

III - se tratar de pedido reipersecutório fundado em prova documental adequada do contrato de depósito, caso em que será decretada a ordem de entrega do objeto custodiado, sob cominação de multa;

IV - a petição inicial for instruída com prova documental suficiente dos fatos constitutivos do direito do autor, a que o réu não oponha prova capaz de gerar dúvida razoável.

Parágrafo único. Nas hipóteses dos incisos II e III, o juiz poderá decidir liminarmente.

51 Nesse sentido: "Trata-se de uma tutela provisória, mas não de urgência, porquanto fundada exclusivamente na evidência do direito, não se cogitando de periculum in mora." (WAMBIER, Ob. cit., 2015, p. 524). 
Duas hipóteses podem ser concedidas liminarmente (incisos II e III), e as quatro podem ser deferidas após a oitiva do réu, conforme prevê o parágrafo único. A razão para essa diferenciação está no fato de, como se verá, as previsões dos incisos I e IV dependerem do comportamento processual do réu (motivo pelo qual não podem ser deferidas antes de sua primeira manifestação, pelo menos), enquanto aquelas dos incisos II e III independem da oitiva prévia do réu (logo, podem ser concedidas no juízo de admissibilidade da petição inicial, o que não impede que também sejam deferidas no curso do processo, após a resposta do réu). Ressalva-se, contudo, que não há tutela da evidência antecedente, porque o seu pedido é sempre formulado com o pedido principal, de tutela definitiva, razão pela qual é sempre incidental.

A primeira hipótese está prevista como ensejadora da tutela antecipada do CPC/73 (art. 273, II), e deriva, no novo Código, dos princípios da boa-fé objetiva e da cooperação (arts. 5o e 6o).

$\mathrm{O}$ autor tem direito à tutela da evidência (incidental) quando o réu cometer abuso no exercício de seu direito de defesa, ou demonstrar manifesto propósito protelatório no andamento do processo. As duas condutas não possuem uma descrição objetiva e são construídas na prática dos tribunais. Em regra, estão relacionadas com o uso dos instrumentos processuais em excesso (os recursos, principalmente - por exemplo, os embargos declaratórios em agravo regimental em agravo de instrumento em recurso extraordinário), ou de forma contrária à lei e às provas (como o requerimento de produção de prova testemunhal sobre fatos já demonstrados por prova documental ou pericial) ${ }^{52}$, ou em desacordo com súmula ou jurisprudência de Tribunal, ou com a reiteração das mesmas alegações nas peças processuais (por exemplo, o réu vencido repete os mesmos argumentos na contestação, na apelação, em embargos declaratórios, em recurso especial, extraordinário, agravo de instrumento etc.). ${ }^{53}$

52 De forma similar ao art. 400, II, do CPC/73, o art. 443, II, do novo CPC, prevê que "o juiz indeferirá a inquirição de testemunhas sobre fatos: II - que só por documento ou por exame pericial puderem ser provados".

53 "A defesa deve ser abusiva, excessiva, anormal, inadequada, com o propósito de frustrar e/ou atrasar a prestação jurisdicional. É interessante observar que o réu pode apresentar defesa técnica adequada e mesmo assim abusar do direito de defesa, que deve ser lido consoante o princípio da ampla defesa, abarcando não só as peças confec-

Resenha Eleitoral (Florianópolis), v. 20, n. 1, p. 171-199, jul. 2016 
O inciso II do art. 311 condiciona a concessão da tutela da evidência ao cumprimento de dois requisitos: (a) comprovação documental das alegações de fato (e a desnecessidade de demonstração por outros meios); e (b) existência de tese fixada em súmula vinculante (do STF) ou em julgamento de caso repetitivo (do STF, STJ ou do Tribunal ao qual o julgador estiver vinculado) no mesmo sentido do pedido do autor. A menção genérica, pelo dispositivo, da expressão "julgamento de casos repetitivos", abrange tanto o julgamento dos recursos extraordinário e especial repetitivos pelo STF e STJ, respectivamente (arts. 1.036/1.041), quanto o incidente de resolução de demandas repetitivas - IRDR (arts. 976/987), de competência dos Tribunais. Além dessas hipóteses, defende-se a possibilidade de concessão da tutela da evidência com base em súmula de tribunal (STJ, TSE, TST, STM, ou outro tribunal ao qual o julgador estiver vinculado), e não apenas nas súmulas vinculantes do STF. ${ }^{54}$

Ainda, na linha do entendimento do STF acerca da eficácia de suas decisões a partir da publicação (e mesmo antes do trânsito em julgado) ${ }^{55}$, o Enunciado no 31 da ENFAM dispõe que "a concessão da tutela

cionadas a esse título (contestação, reconvenção etc.) como também a conduta do réu na defesa de seus interesses." (WAMBIER, Ob. cit., 2015, p. 524).

54 De acordo com o Enunciado no 30 da ENFAM: "É possível a concessão da tutela de evidência prevista no art. 311, II, do CPC/2015 quando a pretensão autoral estiver de acordo com orientação firmada pelo Supremo Tribunal Federal em sede de controle abstrato de constitucionalidade ou com tese prevista em súmula dos tribunais, independentemente de caráter vinculante.".

55 Nesse sentido, por exemplo: CONSTITUCIONAL E PROCESSUAL CIVIL. DECLARAÇÃO DE INCONSTITUCIONALIDADE DE PRECEITO NORMATIVO PELO SUPREMO TRIBUNAL FEDERAL. EFICÁCIA NORMATIVA E EFICÁCIA EXECUTIVA DA DECISÃO: DISTINÇÕES. INEXISTÊNCIA DE EFEITOS AUTOMÁTICOS SOBRE AS SENTENÇAS JUDICIAIS ANTERIORMENTE PROFERIDAS EM SENTIDO CONTRÁRIO. INDISPENSABILIDADE DE INTERPOSIÇÃO DE RECURSO OU PROPOSITURA DE AÇÃO RESCISÓRIA PARA SUA REFORMA OU DESFAZIMENTO. 1. A sentença do Supremo Tribunal Federal que afirma a constitucionalidade ou a inconstitucionalidade de preceito normativo gera, no plano do ordenamento jurídico, a consequência (= eficácia normativa) de manter ou excluir a referida norma do sistema de direito. 2. Dessa sentença decorre também o efeito vinculante, consistente em atribuir ao julgado uma qualificada força impositiva e obrigatória em relação a supervenientes atos administrativos ou judiciais (= eficácia executiva ou instrumental), que, para viabilizar-se, tem como instrumento próprio, embora não único, o da reclamação prevista no art. 102, I, "l”, da Carta Constitucional. 3. A eficácia 
de evidência prevista no art. 311, II, do CPC/2015 independe do trânsito em julgado da decisão paradigma.".

Por sua vez, o inciso III diz respeito à ação de depósito, procedimento especial previsto nos arts. 901 a 906 do CPC/73, o qual seguirá o procedimento comum no novo $\mathrm{CPC}$. $\mathrm{O}$ autor tem direito à tutela da evidência quando apresentar: (a) pedido reipersecutório, ou seja, formulado pelo proprietário de bem que não está na sua posse; (b) e instruído com o contrato de deposito e prova da mora do devedor. ${ }^{56}$ Trata-se de uma tutela específica, consistente na entrega do bem, pelo réu ao autor, sob pena de multa.

Finalmente, a tutela da evidência (incidental) pode ser concedida quando (a) a petição inicial estiver instruída com prova documental suficiente para demonstrar os fatos constitutivos do direito; e (b) o réu não produzir provas satisfatórias para gerar dúvida razoável sobre o direito do autor. Trata-se de utilização de standard probatório, influência do direito dos Estados Unidos. ${ }^{57}$ Essa hipótese de tutela da evidência

executiva, por decorrer da sentença (e não da vigência da norma examinada), tem como termo inicial a data da publicação do acórdão do Supremo no Diário Oficial (art. 28 da Lei 9.868/1999). É, consequentemente, eficácia que atinge atos administrativos e decisões judiciais supervenientes a essa publicação, não os pretéritos, ainda que formados com suporte em norma posteriormente declarada inconstitucional. 4. Afirma-se, portanto, como tese de repercussão geral que a decisão do Supremo Tribunal Federal declarando a constitucionalidade ou a inconstitucionalidade de preceito normativo não produz a automática reforma ou rescisão das sentenças anteriores que tenham adotado entendimento diferente; para que tal ocorra, será indispensável a interposição do recurso próprio ou, se for o caso, a propositura da ação rescisória própria, nos termos do art. 485, V, do CPC, observado o respectivo prazo decadencial (CPC, art. 495). Ressalva-se desse entendimento, quanto à indispensabilidade da ação rescisória, a questão relacionada à execução de efeitos futuros da sentença proferida em caso concreto sobre relações jurídicas de trato continuado." (RE 730462/SP, Pleno, rel. Min. Teori Zavascki, j. 28/05/2015, DJe 08/09/2015).

56 Apesar de o inciso III do art. 311 não fazer menção, a mora do devedor também deve ser comprovada, a fim de demonstrar o descumprimento do contrato pelo réu e o direito do autor à posse do bem. Nesse sentido, prevê o Enunciado no 29 da ENFAM: "Para a concessão da tutela de evidência prevista no art. 311, III, do CPC/2015, o pedido reipersecutório deve ser fundado em prova documental do contrato de depósito e também da mora.".

57 Os três principais standards probatórios são: (a) "preponderance of evidence" (preponderância de provas), exigidos para os casos cíveis, de modo geral; (b) "clear and convincig evidence" (prova clara e convincente), incidente sobre casos cíveis espe-

Resenha Eleitoral (Florianópolis), v. 20, n. 1, p. 171-199, jul. 2016 
não se confunde com as situações de dispensa de dilação probatória e de pedido incontroverso, as quais possibilitam o julgamento antecipado do mérito (total e parcial, nos termos dos arts. 355, I, e 356, I, do novo CPC).

Ademais, questão que certamente causará controvérsia é a extensão - ou não - da tutela da evidência nas hipóteses de proibição de concessão de medida liminar contra a Fazenda Pública. Em sentido contrário, o Enunciado no 35 do FPPC prevê que "as vedações à concessão de tutela antecipada contra a Fazenda Pública não se aplicam aos casos de tutela de evidência.".

Para resolver a questão, duas situações devem ser diferenciadas: (a) proibições legais de concessão de tutela cautelar ou antecipada não impedem a concessão da tutela da evidência, por se tratarem de espécies distintas de tutela provisória; (b) as vedações genéricas ao deferimento de medida liminar ${ }^{58}$ contra a Fazenda Pública abrangem qualquer forma de tutela provisória, seja de urgência, seja da evidência.

\section{Reflexos da Tutela Provisória do Novo CPC no Processo Eleitoral}

As mudanças realizadas pelo novo CPC sobre a tutela provisória refletem sobre o processo eleitoral, conforme determina de forma expressa o seu art. 15: " $\mathrm{Na}$ ausência de normas que regulem processos eleitorais, trabalhistas ou administrativos, as disposições deste Código lhes serão aplicadas supletiva e subsidiariamente.”.

Apesar da ausência de normas similar no CPC/73, por se tratar de norma geral os Códigos de Processo Civil anteriores já produziam reflexos sobre as leis processuais especiais (inclusive no processo eleitoral), independente de regra expressa. Ademais, o novo Código realiza de forma parcialmente adequada a distinção entre aplicação: (a) supletiva, que busca preencher uma lacuna, quando a lei processual especial não regulamentar o tema, ou contiver omissões na regulamentação; e (b)

cíficos (c) e "evidence beyond a reasonable doubt" (prova além de qualquer dúvida razoável), aplicável ao processo penal. Sobre o assunto: KNIJNIK, Danilo. A prova nos juízos cível, penal e tributário. Rio de Janeiro: Forense, 2007, p. 37-45.

58 Compreendida, em sentido amplo, como a tutela prestada em cognição sumária, em momento anterior à sentença.

Resenha Eleitoral (Florianópolis), v. 20, n. 1, p. 171-199, jul. 2016 
subsidiária, que busca auxiliar no tratamento do assunto, quando a lei processual especial regulamentar o tema, mas necessitar de auxílio na interpretação ou aplicação da norma, por um princípio ou regra do Código de Processo Civil. Em suma, a incidência supletiva pressupõe a omissão, enquanto a subsidiária não depende de lacuna. ${ }^{59}$

A distinção está parcialmente correta tendo em vista que, apesar de fazer menção expressa à aplicação subsidiária e supletiva, o citado art. 15 do novo Código inicia justificando essas formas de integração nos casos de "ausência de normas". Como visto, a existência de normas não impede a utilização subsidiária do CPC na aplicação de outras leis, inclusive, em processos administrativos e judiciais, trabalhistas e eleitorais.

Assim, o novo Código de Processo Civil deixa claro que não regulamenta apenas o processo civil, mas o processo cível (ou seja, de natureza não penal), de forma subsidiária e supletiva; por isso, deve ser utilizado como base principal para a interpretação e a aplicação de todas as normas processuais no Brasil, previstas em outros Códigos e em leis especiais, ou daquelas inseridas por meio de tratados internacionais incorporados ao ordenamento jurídico nacional.

Em consequência, a tutela de urgência (cautelar ou antecipada) no processo eleitoral deve ser prestada apenas mediante requerimento, sendo vedada a sua concessão de ofício (arts. 295, 299, 303 e 305 do CPC/2015), permitida somente a modificação e a revogação de ofício (art. 296).

Ainda, a tutela de urgência - antecipada e cautelar - possui dois requisitos genéricos (art. 300): (a) a probabilidade do direito (fumus boni

59 "O legislador disse menos do que queria. Não se trata somente de aplicar as normas processuais aos processos administrativos, trabalhistas e eleitorais quando não houver normas, nestes ramos do direito, que resolvam a situação. A aplicação subsidiária ocorre também em situações nas quais não há omissão. Trata-se, como sugere a expressão "subsidiária", de uma possibilidade de enriquecimento, de leitura de um dispositivo sob um outro viés, de extrair-se da norma processual eleitoral, trabalhista ou administrativa um sentido diferente, iluminado pelos princípios fundamentais do processo civil. A aplicação supletiva é que supõe omissão. Aliás, o legislador, deixando de lado a preocupação com a própria expressão, precisão da linguagem, serve-se das duas expressões. Não deve ter suposto que significam a mesma coisa, se não, não teria usado as duas. Mas como empregou também a mais rica, mais abrangente, deve o intérprete entender que é disso que se trata.”. (WAMBIER, Ob. cit., 2015, p. 75).

Resenha Eleitoral (Florianópolis), v. 20, n. 1, p. 171-199, jul. 2016 
iuris); e (b) o perigo de dano ou o risco ao resultado útil do processo (periculum in mora).

Com a unificação da regulamentação das tutelas cautelar e antecipada como espécies da tutela de urgência, aplicam-se-lhes as normas sobre a prestação de caução (real ou fidejussória) como condição para o deferimento (art. 300, $1^{\circ}$ ), a realização de audiência de justificação prévia para a concessão liminar (art. 300, §2º), e a existência de um requisito contrário à concessão da tutela de urgência, consistente no perigo de irreversibilidade dos efeitos da decisão (art. 300, §3ํㅜ).

As duas espécies de tutela de urgência (cautelar e antecipada) podem ser prestadas de forma antecedente ou incidental, mas não há um processo autônomo: o requerimento é apresentado na petição inicial, juntamente com o pedido de tutela definitiva, ou em petição posterior.

Excepcionalmente a tutela de urgência pode ser requerida isoladamente na petição inicial, mas posteriormente a parte autora deve aditá-la para inserir o pedido principal, nos mesmos autos. Nesta hipótese o novo CPC regulamenta a estabilização da tutela antecipada (art. 304), consistente na manutenção da eficácia da decisão que deferir a antecipação da tutela, independentemente de instrução posterior ou de sentença de mérito. Não havendo recurso, a decisão em cognição sumária se torna estável e o processo é extinto sem resolução do mérito, e eventual alteração só pode ser realizada em ação própria (ação de revisão, reforma ou invalidação), proposta pelo réu no prazo decadencial de 2 anos.

Outra novidade importante, e também incidente ao processo eleitoral, é a responsabilidade civil objetiva da parte beneficiada pela tutela de urgência (que for posteriormente revogada), pelos danos que causar à parte contrária (art. 302).

Por fim, a tutela provisória da evidência também será adotada no processo eleitoral na maior parte das hipóteses do art. 311. Assim, por exemplo, a prova documental suficiente das alegações de fato do autor contra a qual o réu não produzir prova que cause dúvida razoável, pode levar à efetivação da tutela da evidência antes da sentença, independentemente da demonstração de urgência. Em consequência, no processo eleitoral poderá ser concedida a tutela da evidência em ações de perda de mandato eletivo, cassação de diploma, rejeição de contas (entre outras), dispensada a prova de urgência. 


\section{Conclusões}

O novo CPC unificou a regulamentação da tutela prestada de modo antecedente ou incidental nas fases de cognição e de execução do processo cível, por meio do gênero tutela provisória, que se divide nas espécies tutela de urgência e tutela da evidência.

Enquanto no $\mathrm{CPC} / 73$ a antecipação de tutela era uma técnica processual de concessão da tutela jurisdicional, efetivada por meio de provimento de natureza satisfativa, a tutela cautelar consistia em tutela jurisdicional preventiva, efetivada por meio de provimento de preservação.

O novo CPC modifica e unifica essa diferenciação, ao tratar a tutela provisória como técnica de concessão da tutela jurisdicional, com provimentos de natureza antecipada ou cautelar, antecedente ou incidente, estabelecendo um regime jurídico unificado para a tutela de urgência, subdividida em antecipada e cautelar (que podem ser concedidas em caráter antecedente ou incidental).

Consequentemente, o distanciamento de diversos Livros, Títulos, Capítulos, Seções, artigos, alíneas e parágrafos existentes no CPC de 1973 entre as tutelas antecipada (art. 273) e cautelar (art. 796 e seguintes) foi suprimido pelo novo Código, que os uniu no final da Parte Geral, com Título específico dentro do Livro V, destinado especificamente ao estabelecimento de suas regras, com algumas diferenças nos respectivos procedimentos.

Ainda: o novo CPC confere total efetividade ao sincretismo processual, tendo em vista que, a partir de sua entrada em vigor, as tutelas de cognição, cautelar e de execução serão prestadas em um só processo.

Entre as novidades na matéria, viu-se que a tutela de urgência não pode ser concedida de ofício, mas apenas mediante requerimento da parte, no entanto, por outro lado, pode ser revogada ou modificada de ofício. Também se destacam a estabilização da tutela antecipada, a responsabilidade civil objetiva da parte beneficiada pela tutela posteriormente revogada e, por fim, as principais características e hipóteses de concessão da tutela da evidência, concedida com base na prova do direito e independentemente de urgência. 
Destacou-se, por fim, que as modificações promovidas pelo novo Código refletem sobre o direito eleitoral são aplicáveis a todos os processos em tramitação, ainda que iniciados antes de sua entrada em vigor.

\section{Referências}

ALVIM, Arruda; ASSIS, Araken de; ALVIM, Eduardo Arruda. Comentários ao Código de Processo Civil. 2. ed. São Paulo: RT, 2012.

AMARAL, Guilherme Rizzo. Comentários às alterações do novo CPC. São Paulo: RT, 2015.

BUENO, Cassio Scarpinella. Curso sistematizado de direito processual civil: teoria geral do direito processual civil. 3. ed. v. 1. São Paulo: Saraiva, 2008 .

Paulo: Saraiva, 2015.

. Novo Código de Processo Civil anotado. São

CÂMARA, Alexandre Freitas. Juizados especiais cíveis estaduais e federais: uma abordagem crítica. 4. ed. Rio de Janeiro: Lumen Juris, 2008.

DINAMARCO, Cândido Rangel. Nova era no processo civil. São Paulo: Malheiros, 2004.

KNIJNIK, Danilo. A prova nos juízos cível, penal e tributário. Rio de Janeiro: Forense, 2007.

MACHADO, Antônio Cláudio da Costa. Código de processo civil interpretado. 4. ed. Barueri: Manole, 2004.

MITIDIERO, Daniel. Antecipação da tutela: da tutela cautelar à técnica antecipatória. São Paulo: RT, 2013.

NERY JUNIOR, Nelson; NERY, Rosa Maria de Andrade. Código de processo civil comentado e legislação extravagante. 14. ed. São Paulo: RT, 2014.

THEODORO JÚNIOR, Humberto. Curso de direito processual civil. v. I. 41. ed. Rio de Janeiro: Forense, 2004. 
ed. v. 2. Rio de Janeiro: Forense, 2008.

. Curso de direito processual civil. 42.

VAZ, Paulo Afonso Brum. Manual da tutela antecipada: doutrina e jurisprudência. Porto Alegre: Livraria do Advogado, 2002.

WAMBIER, Luiz Rodrigues; TALAMINI, Eduardo Talamini. Curso avançado de processo civil. v. 1. 13. ed. São Paulo: RT, 2013.

WAMBIER, Teresa Arruda Alvim; CONCEIÇÃO, Maria Lúcia Lins; RIBEIRO, Leonardo Ferres da Silva; MELLO, Rogério Licastro Torres de. Primeiros comentários ao novo Código de Processo Civil artigo por artigo. São Paulo: RT, 2015.

ZAVASCKI, Teori Albino. Antecipação de tutela. 7. ed. São Paulo: Saraiva, 2009.

Oscar Valente Cardoso - Juiz Federal na $4^{a}$ Região. Doutorando em Direito (UFRGS). Mestre em Direito e Relações Internacionais (UFSC). Professor da Escola Superior da Magistratura Federal de Santa Catarina (ESMAFE-SC). 